\title{
WEB-BASED IMPLEMENTATION OF E-MARKETING TO SUPPORT PRODUCT MARKETING OF CHEMICAL MANUFACTURING COMPANY
}

\author{
Riswan Efendi Tarigan \\ Department of Information Systems \\ Faculty of Computer Science \\ Pelita Harapan University \\ Jakarta 15811, Indonesia \\ Email: kartika.saridewi92@gmail.com
}

\author{
Kartika Sari Dewi \\ Department of Information Systems \\ Faculty of Computer Science \\ Pelita Harapan University \\ Jakarta 15811, Indonesia \\ Email: re.tarigan@gmail.com
}

\begin{abstract}
Currently, marketing strategies in many companies are limited only to face-to-face communication, telephone, facsimile, company portfolio, and product brochures. However, those marketing strategies are wellknown to have limited impacts. Therefore, the presence of e-marketing as one of the marketing strategies would be appropriate to cover the weaknesses and to solve a number of the marketing problems. The purpose of this study is to discuss matters related to marketing, such as, proposing a marketing plan using website, expanding marketing segment, and introducing existing products for a chemical manufacturing company. The adopted research method is a descriptive method where the study is directly performed on the research object to acquire necessary data. The collected data are further analyzed using the Porter's Five Force and SWOT analysis. Finally, the work provides a number of recommendations for implementing e-marketing strategies to support the company business.

Keywords: e-business; e-marketing; website
\end{abstract}

\section{INTRODUCTION}

In the era of globalization, there are many significant changes in economy and business world. The enterpreneurs should pay attention to their business systems since technology development creates new emerging threats in the world of business competition. In these conditions, enterpreneurs must take aggressive and significant measures to maintain the continuity of the business they pioneered, so that they remain able to survive and thrive. It takes new marketing strategies and innovation in improving the performance of marketing department of a company in order to be

Received: March 22, 2015; received in revised form: April 6, 2015; accepted: May 14, 2015; available online: June 17, 2015. able to compete well. One of the marketing strategies that are being developed at this time is the Internetbased marketing.

Internet can connect one computer to another across the world and it creates the nascent idea of using internet technology for business processes or it is also known as e-business [1]. E-business is an innovation of business processes that is triggered by technological progress [2]. It is able to meet the needs of the consumers and manufacturers in the business process [3]. The implementation of e-business has been shifted in fundamental paradigm, from the original marketplace that emphasizes physical interaction between sellers and buyers into the marketplace that relies on electronic transactions [4]. E-business covers all kinds of functions and business events that use electronic data and one of them is an e-marketing [5]. Implementation of e-marketing management system for marketing department of a company has a goal to increase revenue by expanding their marketing scope by using internet. E-marketing provides the possibility to exchange data between one company to another company over the web, internet, intranet, extranet, or a combination of them [6-8].

With the development of information technology at the moment, there are a lot of opportunities for entrepreneurs to expand and strengthen their existing marketing network. Companies can implement emarketing system that is part of e-business by utilizing and using company's website. E-marketing offers two very important benefits for business sector. First, e-marketing increases the scope of organizations or 
Cite this article as: R. E. Tarigan and K. S. Dewi, "Web-based implementation of e-marketing to support product marketing of chemical manufacturing company," CommIT (Communication \& Information

Technology) Journal 9(2), 73-82, 2015.

businesses as it is defined by the growing number of potential customers of their products. This advantage extends to both large and small businesses.

Second, e-marketing is able to eliminate many of the barriers that previously inhibit entrepreneurs to start a business. Although e-marketing is utilized, company must have a viable method to market their products and generate revenue.

Marketing is a method to market products manufactured by a company or organization. Marketing is not just limited to how the product is sold but it includes promotion, pricing and distribution of ideas. Promotion can be done by creating a website of business transaction between the user and the owner made. The website is not only for business transactions but is also for the brand image of the company.

Chemical Manufacturing Company (CMC) is a paint manufacturer that strives to keep their supporting distributors and paint stores in selling their products. The marketing expand their products to industrial and individual users. Expansion of marketing is also to introduce their products and determine what kinds of paint products that match customers needs. The company strives to do the branding of their products in order to make them more recognized in the industry and society. In terms of marketing, the company experiences problems due to the large number of competitors and the brand image of the preceding brand paint, while the product to be marketed by CMC is a relatively new paint product. This study is to explore whether the application of e-marketing is able to increase the company's revenue and assist the process of branding products in the industry and society or not.

\section{SUPPORTING THEORIES}

\section{A. E-business}

According to Ref. [9], e-business is the practice of implementation and management of key business processes such as product design, raw material supply management, manufacturing, sales, order fulfillment, and the provision of services through the use of communications technology, and computer. The definition of e-business by Ref. [10] is an approach that is secure, flexible, and integrated to deliver business value by combining different systems and processes that run major business operations with the use of internet technology. By some definitions of e-business mentioned above, e-business is the application of information and communication technologies by organizations, individuals, or parties in relation to running and managing key business processes to provide benefits in the form of security, flexibility, integration, optimization efficiency, increasing productivity and profit.

\section{B. E-marketing}

Electronic Marketing (e-marketing) can be seen as, a new philosophy and modern business practices in the marketing of goods, services, information and ideas through the Internet and other electronic networks. By reviewing the literature similarities, the definition of e-marketing varies according to each author's perspective, background and specialization. Reference [11] defines e-marketing is achieving marketing objectives through applying digital technologies and Ref. [12] defines e-marketing is the use of electronic data and applications for planning and excuting the conception, distribution and pricing of ideas, goods and services to create exchange that satisfies individual and organizational goals. The main obstacle, many people are still wrong in defining the term of e-marketing, internet marketing, e-commerce, e-business in the same sense, when all the terms are different. For example, e-marketing has a broader scope compared to Internet Marketing. Internet Marketing simply refers to the Internet, the World Wide Web, and e-mail. However, e-marketing includes all that plus an intra-net, extranet and mobile phones. In contrast to this, e-commerce and e-business has wider coverage and comprehensive e-marketing. The difference can be seen in Fig. 1. Implementation of web-based e-marketing is done by increasing the use of internet marketing that not only creates a lot of opportunities for small businesses but also eliminates a lot of threat.

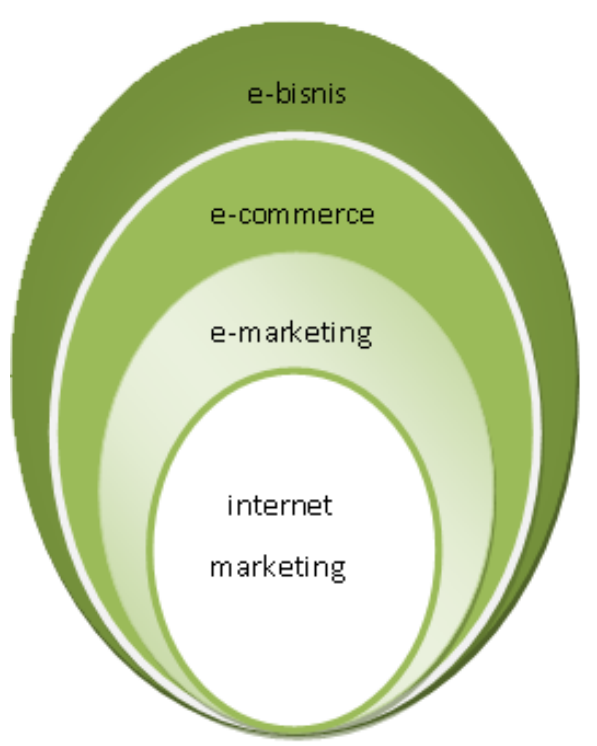

Fig. 1. The scopes of e-business and e-marketing. 
Cite this article as: R. E. Tarigan and K. S. Dewi, "Web-based implementation of e-marketing to support product marketing of chemical manufacturing company," CommIT (Communication \& Information

Technology) Journal 9(2), 73-82, 2015.

\section{Marketing}

Reference [13] defines marketing as a societal process by which individuals and groups obtain what they need and want through creating, offering and freely exchanging products and services of value with others. Reference [14] defines marketing as the planning and implementation of an idea or concept, price, promotion and distribution. Marketing can mean simply that marketing is the construction and maintenance of a mutually satisfactory relationship between companies and consumers. According to Ref. [15], marketing is a total system of business activities designed to plan, determine price, promote and distribute goods that meet the need of people and achieve the market target as well as the company's goals. So it can be concluded that marketing is a whole system of business activities, which is intended to make planning, pricing, promoting, and distributing goods and services that meet the needs of the buyer and the benefit of the seller. The role of marketing is very important since marketing is a source of companys revenue that determines the development of the company.

\section{Website}

According to Ref. [16], website is a collection of web pages owned by an individual or a company. Websites or often abbreviated to site are a number of web pages that have inter-related topics, sometimes accompanied by files of images, videos, or other file types. A web site is usually placed at least on a web server that can be accessed over a network such as the Internet, or a local area network (LAN) via the Internet addresses that are recognized as URL. All publicly accessible sites on the internet are also referred to as the World Wide Web, or better known by the acronym WWW.

\section{E. SWOT Analysis}

According to Ref. [17], SWOT analysis is a tool that is used for preparing the strategic factors of the company, or a systematic analysis to identify factors strengths, internal weaknesses of the company and the opportunities and threats in the environment faced by the company. The SWOT components are shown in Fig. 2.

\section{F. Porter's Five Force}

Porter Five Forces competitive analysis so far is the most widely used framework for the assessment of profit potential in the industry. The collective power is formed by the so-called five different strengths from industry to industry. Each of these five forces based on structural features (dimensions) which collectively

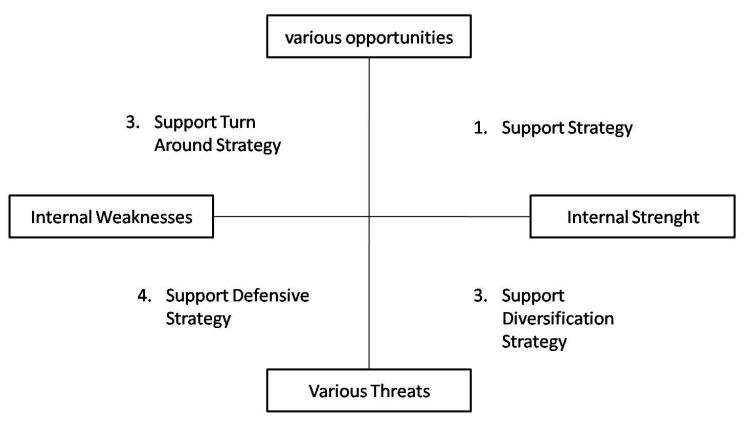

Fig. 2. The components of the SWOT analysis.

have an impact on the profit potential. All the five powers jointly determine the intensity of industry competition and profitability. The strongest power is important from the point of view of strategy formulation. Here are the components of the five forces porter:

1) Barriers to Entry. This is an important structural component of the industry to limit or prohibit the entry of new competitors. The main components of economies of scale are (the advantage of experience, learning and volume), differentiation (brand image and loyalty), capital requirements (newcomer would face a risk premium), switching costs involved with customers, access to distribution channels and lack of funds (patents, location, subsidies).

2) Rivalry Among Existing Competitors. In most industries, especially when there are only a few major competitors. Aggressiveness will depend primarily on factors such as the number of competitors, the growth of the industry, the high costs, lack of differentiation, the addition of a large capacity, diversity of competitors and the importance of business strategy.

3) Substitution. It is a product or solution that basically performs the same function but are often based on different technologies, depending on the level of abstraction almost all of which can be a substitute. In general, the only factor that really matters is the shift in technology.

4) Buyer Strength. Through their bargaining power, buyers can force competitors to lower their prices or better quality service. Factor that determine bargaining power is volume. Such products represent a significant portion of the cost or purchase, standard product differentiation, profitability, threats of backward integration, final product quality, as well as the buyer's knowledge 
Cite this article as: R. E. Tarigan and K. S. Dewi, "Web-based implementation of e-marketing to support product marketing of chemical manufacturing company," CommIT (Communication \& Information

Technology) Journal 9(2), 73-82, 2015.

and information level on demand industry, such as the actual market price and the supplier's costs.

5) Supplier Strength. Suppliers can exert their bargaining power over buyers by threatening to raise prices or reduce quality. A group of supplier is said to be strong if they are more concentrated than the industry in which they make a sale, or if the customer group is not important to the supplier, the product is an important input for the business buyer or supplier groups pose a threat to the future integration

The study of Ref. [18] uses quantitative and descriptive method to design web-based e-marketing that is intended to facilitate customers in finding information about Sumber Cellular in order to make efficient and effective marketing. Reference [19] also conducts research using quantitative and descriptive method that addresses the adoption of web-based e-marketing to increase market share and the effectiveness and efficiency of Cellular88 marketing.

Based on those two studies, an analysis and implementation of web-based e-marketing using a quantitative approach and SWOT analysis is made. Thus, it contributes relevant elements contained in the analysis of marketing strategies that can be applied by looking at the situation and condition of a company in order to survive and compete.

\section{RESEARCH METHODS}

The study intends to understand the customer preferences in using a web-based e-marketing site to interact with a chemical manufacturing company. For the purpose, the study adopts a descriptive approach where the customer opinions are collected through questionnaires, interviews, and direct observations from those who have the experience of using the CMC website. The company has about 20 groups of customers. The data are collected in 1 week.

The study hypotheses are of the following:

H1: For the CMC and its customer, the use of web-based marketing has positive and significant impacts to the customer satisfaction.

$\mathrm{H} 2$ : The success of CMC marketing is strongly influenced by its deployed strategies.

H3: The success of CMC marketing is strongly influenced by the current development of information technology.

The questionnaires contain statements with options of responses in Likert scale. For each statement, the available options are 'Strongly Disagree', 'Disagree', 'Doubtful', 'Agree', and 'Strongly Agree'.

\section{RESULTS AND DISCUSSION}

\section{A. The Analysis of the Marketing Analysis}

The Chemical Manufacturing Company (CMC) has applied the following marketing strategies to maintain its competitiveness.

The first strategy is in the aspect of competitive prices. With this strategy, the CMC is able to survive and compete with other similar companies. The company offers paint products with lower prices but maintains the product quality.

The second strategy is by maintaining the company focus on the market opportunities. The CMC products are always oriented to customer satisfaction. The company always analyzes its products and customizes the products the suit the customer needs. The company also often conducts the field surveys to understand the customer requirements.

The third strategy is by product differentiation. Using this strategy, the CMC only serves the needs of some specific consumer groups with certain types of products as well. So, companies or manufacturers produce and market different products for each market segment. In other words, companies or manufacturers offer a wide variety of products and product mix that are tailored to the needs and desires of different groups of consumers or buyers. With its own marketing program, the company expects to achieve the highest level of sales in each of these market segments. The company uses this strategy to strengthen the confidence of certain groups of consumers for products that are produced and marketed, so that the purchase will be carried out repeatedly. It is expected that the company's sales will increase and the position of the company's products will be more stable in this segment of the market. This strategy was applied by continuing to produce and introduce new products as well as putting out some quality products with a wide range of packaging, so customers can buy according to their needs.

The fourth strategy is by providing a better approach to customers and distributors. CMC always keeps customer satisfaction and distributors spread across several cities. This is done by providing a demo of how to use the right products to the consumers so that consumers get the maximum results. Approach to distributors is conducted by always keeping the commitments and supporting promotional programs to enable distributors to sell the products in the market

The fifth strategy is by integrating the distribution channels. This strategy determines the method of delivery of the products or services to market via routes that are effective to arrive at the right place. This is done so that the products or services according to the 
Cite this article as: R. E. Tarigan and K. S. Dewi, "Web-based implementation of e-marketing to support product marketing of chemical manufacturing company," CommIT (Communication \& Information

Technology) Journal 9(2), 73-82, 2015.

needs and desires of consumers who use the products or services. CMC ensures a smooth flow of shipping their products by setting up offices and warehouses in several areas such as Cirebon, Surabaya, etc. Normally, the goods ordered must await shipment from head office, just after it, the goods are distributed to the various regions. This is what is modified by CMC. They set up offices and warehouses in 30 regions, so consumers no longer need to wait for the goods from head office since employees of the CMC will distribute the goods from the office closest to the location of the consumer. According to the company, it is also beneficial for the consumer in case the damage to the product shipped. Thus, consumers can claim damage product to the nearest office and get a replacement if the company's products are proved to be inaccordance with company standards. Consumers do not need to send back the product back to head office to get a replacement.

The sixth strategy is by product promotion. This strategy is associated with a variety of businesses to provide information to the market about the products or services sold, place and time. Promotion undertaken by $\mathrm{CMC}$ are via personal selling and sales promotion. In the personal selling, $\mathrm{CMC}$ carries out direct contact to prospective customers. This direct contact or interaction will create a positive relationship between the employer and the prospective customers. Personal selling is done by telephone selling, and direct selling. In sales promotion, $\mathrm{CMC}$ employs some salesmen to market the company's products to the public in order to be able to increase the company's sales. The promotion consists of a variety of ways, for example, selling the product around a building, exhibitions, presentations, handing out brochures, etc. in order to attract public attention to the product being sold.

Figure 3 is a percentage of the marketing strategy analysis by the CMC. Based on Fig. 3, it can be seen

\section{ANALISIS STRATEGI PEMASARAN PT. BINTANG CHEMICAL INDONESIA}

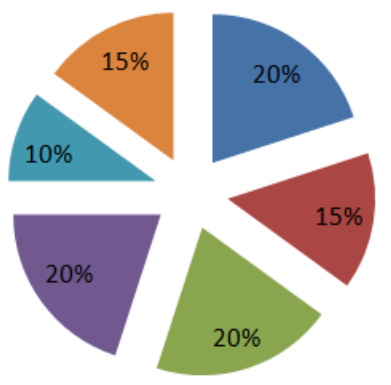

- Harga yang Bersaing dengan Kompetitor n Fokus pada Peluang Pasar

Diferensiasi Produk

- Pendekatan terhadap Konsumen dan Distributor - Saluran Distribusi yang Terintegrasi - Promosi

Fig. 3. The percentage of PMK Marketing Strategy Analysis. that the marketing strategies applied by CMC have the same relative percentages. The marketing strategy is applied not only to have a combination of activities or strategies of the best, but also to coordinate other strategies according to the situation and condition of the company, so marketing can be done effectively and efficiently.

\section{B. Analysis of the Development of the Information Technology}

Information technology today has become part of people's lives. Communities know the direct benefits from the development of information technology in their lives. Business is a part of people's lives that are greatly affected by the changes in information technology. Information technology is very important and influential on the development of an industry in business. Information technology makes employees communicating and finishing their job without having physical meeting; such that, the company can achieve productive results in a more efficient way. Information technology offers convenience not only to companies but also to the scope of the company. In the development of today's business world, companies may lag behind its competitors if it does not control or implement information technology in the industry.

In the development of today's business world, companies may lag behind its competitors if it does not control or apply information technology in the industry. The use of information technology is also a parameter of excellence of a company. It is true if at this point the role of information technology can not be separated from the business world. The development of information technology can provide a variety of convenience in conducting business activities such as operational activities, product marketing, and so on.

Based on observations made, the development of information technology in CMC has not yet reached the optimal point. The company has just started to shift from the traditional way in carrying out operational activities such as accounting records and financial statements, recording trading inventory, and others. Information technology will also help the integration of the data from each office of both headquarters and offices in 30 other areas. In the field of marketing, the company still applies private sales and sales promotion. In the area of finance and accounting, companies are still using manual techniques and there is not any computerized system. Therefore, it is necessary to develop systems to apply sales, finance, and accounting for all operational activities to be more effective and efficient, and it can produce maximum results in accordance with its main objectives. It can also improve the 
Cite this article as: R. E. Tarigan and K. S. Dewi, "Web-based implementation of e-marketing to support product marketing of chemical manufacturing company," CommIT (Communication \& Information

Technology) Journal 9(2), 73-82, 2015.

performance of the company that still uses traditional techniques to become modern. In addition, information technology will help the company's product marketing activities through the website so that consumers can see the product of the company without having to wait hours to call and inquire about the company's products or other matters.

\section{Market Observation Results}

In the current research, online preference is a score derived from questionnaire data; see Table I.

The population size is rather large; thus, only data obtained from a sample will be further used. There are many populations so that the whole population may not be investigated due to considerations of time and energy. Therefore, questionnaires are distributed to 20 respondents containing a number of questions related to preferences regarding the use of the website in dealing with chemistry manufacturing company. Table II is the grading of research instrument. Distance from the lowest interval of $0 \%$ to the highest $100 \%$ is 20. Table III shows criteria for the interpretation of the score that is based on the interval

TABLE I

THE INDEPENDENT VARIABLE AND ITS DIMENSION AND INDICATORS.

\begin{tabular}{lll}
\hline Variable & Dimension & Indicators \\
\hline Online & Factors & The effectiveness and efficiency of \\
pre- & affecting & transaction time \\
ferences & preferences & Website display of CMC \\
\cline { 3 - 3 } & & Security on transaction \\
& & Product complete info. \\
\hline
\end{tabular}

TABLE II

GRADING RESEARCH INSTRUMENT.

\begin{tabular}{|c|c|c|c|}
\hline Variable & Dimension & Indicator & \#Questions \\
\hline \multirow{4}{*}{$\begin{array}{l}\text { Online } \\
\text { prefe- } \\
\text { rences }\end{array}$} & \multirow{4}{*}{$\begin{array}{l}\text { Factor } \\
\text { affect- } \\
\text { ing } \\
\text { prefe- } \\
\text { rences }\end{array}$} & $\begin{array}{l}\text { Effectiveness } \\
\text { efficiency }\end{array}$ & 2 \\
\hline & & CMC website & 3 \\
\hline & & Security on transaction & 3 \\
\hline & & Product complete info. & 3 \\
\hline
\end{tabular}

TABLE III

THE SCORES AND THEIR INTERVALS.

\begin{tabular}{clc}
\hline No. & Scale & Interval $(\%)$ \\
\hline 1 & Strongly disagree & $0-19$ \\
2 & Disagree & $20-39$ \\
3 & Uncertain & $40-59$ \\
4 & Agree & $60-79$ \\
5 & Strongly agree & $80-100$ \\
\hline
\end{tabular}

\section{The SWOT Analysis}

Based on the results of observations, interviews, and the obtained data, we establish the results of the SWOT analysis for the CMC company in Table IV with the customer preference scores of those depicted in Table V.

From the results of SWOT analysis of CMC, the strategy can be described in four factors. The four factors of this strategy can indicate the matters that need to be considered and done for the progress and development of the company. ' $\mathrm{S}$ ' and ' $\mathrm{W}$ ' identify internal strengths and weaknesses in this regard related to management functions (planning, organizing, directing, motivating and control). ' $\mathrm{S}$ ' and ' $\mathrm{W}$ ' also identify the strengths and weaknesses of the business functions, namely: marketing and product design; production and supply; human Resources; and finance. ' $\mathrm{O}$ ' and ' $\mathrm{T}$ ' are the external analysis, such as, the opportunities and threats that include aspects of social, technological, economic, political, legal, environmental, demographic, and competitors. Table VI shows SWOT analysis strategies in the form of a matrix

Based on the SWOT analysis CMC, it can be seen that the balance between internal factors and external factors must be considered. Companies need to pay attention to both factors in order to survive and compete with its competitors.

Development of internal factors is indeed an important aspect. However, companies also need to consider and take strategic decisions in dealing with external factors. Creating a balance between internal and external factors is not an easy thing.

\section{E. Porter's Five Force Analysis}

Porter explains that there are three generic strategies to boost the progress of a business, the first is cost leadership, the second is focus and the third is differentiation. Based on observations made, CMC applies two of the three generic strategies. First, CMC offers products at competitive prices while maintaining product quality. Although the market is still wide open, paint market already crowded with various brands. Number of paint brands on the market could reach the hundreds of brands. Of course, this makes paint market competition can not be avoided. The increasingly fierce competition is forcing marketers of paint to make innovations in order to keep their business growing.

Second, CMC takes steps to different by offering a product variant. Products offered by the company are stone coats, wood filler, interior and exterior wall paint, epoxy, melamine, etc. CMC releases different products for different segments. For example, the company produces branded paint Yhingstex for the people of 
Cite this article as: R. E. Tarigan and K. S. Dewi, "Web-based implementation of e-marketing to support product marketing of chemical manufacturing company," CommIT (Communication \& Information Technology) Journal 9(2), 73-82, 2015.

TABLE IV

THE SWOT ANALYSIS OF CMC.

\begin{tabular}{|c|c|c|}
\hline & Strength & Weaknesses \\
\hline 胥 & $\begin{array}{l}\text { 1) Paint does not settle to the bottom and it is thicker. } \\
\text { 2) Paint is not easy to peel and it is resistant to all } \\
\text { weather. } \\
\text { 3) This paint is formulated to increase resistance to mold } \\
\text { and mildew. } \\
\text { 4) Fast drying process, either inside or outside surface. } \\
\text { 5) Using non-hazardous materials. } \\
\text { 6) The colors do not fade quickly. } \\
\text { 7) Having a group of people that are dedicated, educated, } \\
\text { skilled, motivated, intelligent and high integrity. } \\
\text { 8) Having good planning and close cooperation with } \\
\text { suppliers, customers, and distributors. } \\
\text { 9) Having distribution network so that products can be } \\
\text { distributed to remote areas. } \\
\text { 10) All activities are always carried out properly without } \\
\text { neglecting the quality of the product. } \\
\text { 11) Product diversification. } \\
\text { 12) Affordable price with good quality. } \\
\text { 13) The company provides products with various color } \\
\text { options. } \\
\text { 14) The product packaging has been designed as attractive } \\
\text { as possible. }\end{array}$ & $\begin{array}{l}\text { 1) Lack of advertising media that cause lesser known } \\
\text { products. } \\
\text { 2) Still not using information technology effectively. } \\
\text { 3) The slow pace of the company's internal coordination } \\
\text { in decision-making. } \\
\text { 4) The paint can not be washed and it is unlike other } \\
\text { paint products. } \\
\text { 5) Do not have a fresh smell like most other paints. } \\
\text { 6) The number of employees is relatively small thus it is } \\
\text { affecting the company's production process. }\end{array}$ \\
\hline 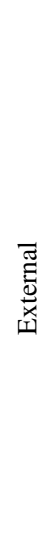 & $\begin{array}{l}\text { 1) The existence of strong economic growth in the major } \\
\text { islands in Indonesia so that the country development } \\
\text { is still growing rapidly. } \\
\text { 2) The breadth of the market potential. } \\
\text { 3) Having a non-hazardous material, so it is likely to be } \\
\text { a superior product. } \\
\text { 4) In general, consumers need a paint that has a lot of } \\
\text { advantages because of the excellence, the customers } \\
\text { can meet their needs.. } \\
\text { 5) Marketing opportunities still open due to increasing } \\
\text { consumer awareness of environmental care in life. }\end{array}$ & $\begin{array}{l}\text { 1) The Company has not aggressively doing promotions } \\
\text { with advertising, so the lack of understanding and } \\
\text { awareness of the advantages of the products of CMC. } \\
\text { 2) A large number of similar products with the same } \\
\text { specifications and the amount of product that offers } \\
\text { a range of advantages with a relatively cheap price } \\
\text { makes CMC is ready to become a competitor in the } \\
\text { competitive marketing of these products. } \\
\text { 3) Brand awareness of the product from CMC is still } \\
\text { lacking due to insufficient promotion to the audience. } \\
\text { 4) The supply of raw materials that is not consistent. } \\
\text { 5) The unstable rupiah against foreign currencies. } \\
\text { 6) Weakening of consumer purchasing power. } \\
\text { 7) Market mindset that relies on the better quality of } \\
\text { foreign products }\end{array}$ \\
\hline
\end{tabular}

the middle to lower class. These factors are believed to be key to the success of CMC to compete.

\section{F. Final Remarks}

Based on customer preference index values obtained from the calculation using a Likert scale, it can be seen that $63.18 \%$ of customers agree to switch to use the website to interact with CMC. It can be seen that the most prominent variable dimensions contained in the web site interface that is equal to $80 \%$. CMC website has an interface that is attractive to customers.

Results of the study provide an understanding that the development of information technology has become an important aspect both in the business world and others. Information technology will be one of the long-term competitive advantages for the company to survive and compete with other competitors. Based on observations and interviews that have been conducted, it is known that some consumers, especially those that have aged over 45 years, still do not believe the transaction via the web site because of the safety factor.

This study can be used as a basis of understanding, that information technology can be an enabler to facilitate customer interaction with CMC. The website has become an important factor in business due to the rapid development of information technology. The website offers a number of long-term benefits to the company because people are able to interact with the company at any time and any place 
Cite this article as: R. E. Tarigan and K. S. Dewi, "Web-based implementation of e-marketing to support product marketing of chemical manufacturing company," CommIT (Communication \& Information Technology) Journal 9(2), 73-82, 2015.

TABLE V

THE CUSTOMER PREFERENCE SCORE.

\begin{tabular}{|c|c|c|c|c|}
\hline \multicolumn{2}{|c|}{ Question } & \multirow{2}{*}{$\begin{array}{c}\text { Score } \\
65\end{array}$} & \multirow{2}{*}{$\begin{array}{c}\text { Percentage } \\
60\end{array}$} & \multirow{2}{*}{$\frac{\text { Description }}{\text { Doubt }}$} \\
\hline $\begin{array}{l}\text { The effectiveness and efficiency of trans- } \\
\text { action time }\end{array}$ & $\begin{array}{l}\text { Does the transaction via our website re- } \\
\text { quire a long time? }\end{array}$ & & & \\
\hline & $\begin{array}{l}\text { Does the transaction via our website re- } \\
\text { quire a long process }\end{array}$ & 65 & 65 & Agree \\
\hline \multirow[t]{3}{*}{ Interface display of CMC website } & Is our company site easy to learn? & 65 & 65 & Doubt \\
\hline & $\begin{array}{l}\text { Does our corporate website facilitate your } \\
\text { search of our products? }\end{array}$ & 65 & 75 & Agree \\
\hline & $\begin{array}{l}\text { Does the presentation of our website in- } \\
\text { terface comfortable to your vision }\end{array}$ & 80 & 75 & Agree \\
\hline \multirow[t]{3}{*}{ Security on transaction } & Do you often use online transactions? & 55 & 50 & Doubt \\
\hline & $\begin{array}{l}\text { Do you entrust our site to carry out a } \\
\text { transaction? }\end{array}$ & 50 & 50 & Doubt \\
\hline & $\begin{array}{l}\text { Do you entrust our site as a means to carry } \\
\text { out a transaction with our company in the } \\
\text { future? }\end{array}$ & 50 & 50 & Doubt \\
\hline \multirow[t]{3}{*}{ Product complete information } & $\begin{array}{l}\text { Does our site provide the most frequently } \\
\text { sought information in general? }\end{array}$ & 65 & 60 & Agree \\
\hline & $\begin{array}{l}\text { Does our website provide all the informa- } \\
\text { tion you need? }\end{array}$ & 65 & 60 & Agree \\
\hline & $\begin{array}{l}\text { Does the provided product information } \\
\text { sufficiently detail? }\end{array}$ & 70 & 70 & Agree \\
\hline
\end{tabular}

TABLE VI

THE MATRIX OF SWOT ANALYSIS STRATEGY ON CMC.

\begin{tabular}{|c|c|c|}
\hline & Strengths & Weaknesses \\
\hline 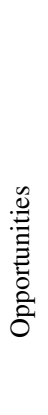 & $\begin{array}{l}\text { 1) Improve product marketing through various media pro- } \\
\text { motion such as advertising on the Internet, websites, } \\
\text { and social media to expand market share. } \\
\text { 2) Allocate human capitals to develop creative products. } \\
\text { 3) Creating products image in order to survive in the } \\
\text { consumers minds. } \\
\text { 4) Creating environmentally friendly and odorless prod- } \\
\text { ucts using non-toxix materials for competitiveness. } \\
\text { 5) Maintain and enhance the product supply chain. } \\
\text { 6) Increase sales by offering products to stores such as } \\
\text { Mitra10 building, Depo building, and so on. } \\
\text { 7) Utilize intranet and internet in the use of information } \\
\text { technology to improve service to the public. }\end{array}$ & $\begin{array}{l}\text { 1) Continue to maximize the promotional products com- } \\
\text { pany that is increasingly recognized by the public. } \\
\text { 2) Improve the ability of skilled human resources in the } \\
\text { use of information technology to streamline service to } \\
\text { the community. } \\
\text { 3) Increase profitability accompanied by the provision of } \\
\text { appropriate facilities to capacity. } \\
\text { 4) Perform research and development to maintain and } \\
\text { improve product quality. } \\
\text { 5) Improve the service by increasing the company equip- } \\
\text { ment quality and availability. } \\
\text { 6) Reduce the amount of liabilities of the company. } \\
\text { 7) Product innovation. }\end{array}$ \\
\hline
\end{tabular}

1) Utilize human resources in the field of technology to keep abreast of the latest information technology.

2) Use the available networks to provide fast, precise, and integrated service, and accurate and important information.

3) Promote products at affordable price aggressively.

4) Enhance the website security to improve customer confidence for online transactions.

5) Produce a higher innovation to anticipate the presence of more creative and unique foreign products.

6) Campaigns for environmentally friendly products.

7) Make a long contract with manufacturer to prevent the threat of the unavailability of raw materials.

8) Conduct research and searching for innovative ideas of products that can still be developed in order to compete with foreign companies.

9) Strengthen the identity of products with tight security so that the product is difficult to forge.
1) Adding human resources that have expertise in the field of information technology for the company's internal set.

2) Increase the availability and quality of the equipment to reduce the impact of rapid technological developments.

3) Improve sales and service network in order to be comparable or even better than the competitors, this is done to satisfy the customers so that they do not switch to other products.

4) Increase oversight of its distributors in order to prevent the debts are not paid.

5) Conducting reviews and evaluations of products that experienced a decline in market share so that the product does not become a burden for the company.

6) Continue to search for alternative resources. 
Cite this article as: R. E. Tarigan and K. S. Dewi, "Web-based implementation of e-marketing to support product marketing of chemical manufacturing company," CommIT (Communication \& Information

Technology) Journal 9(2), 73-82, 2015.

\section{CONCLUSIONS}

Based on study results, the elements contained in the analysis of marketing strategies such as product differentiation, integrated distribution channels, competing products price, promotion, market opportunities focusing, distributors and customers approach must be applied in a balanced manner. However, it has to be done according to the situation and condition of the company for the company to survive and compete.

The development in CMC often takes place quite rapidly and the market opportunities are still wide open. This has become one of the benefits for the company. Therefore, the company needs to assess business strategies in order to increase sales of their products. This can be done by applying web-based emarketing to support the marketing of the company's products. It can be concluded that there is a correlation between the web-based e-marketing strategies of the CMC to customer satisfaction. With the web-based services, it becomes easier for customers to access the available services. This can increase the productivity of companies because marketing is a whole system of the company's activities focused on planning, pricing, promotion and distribution of goods and services to customers

Some customers are still hesitant to switch from the traditional system by using the telephone or fax in interacting with chemistry manufacturing company. However, most customers agree to follow the development of information technology such that interaction with the company can be done through the web site. The company needs to optimize the existing information technology using a more integrated system. All activities undertaken by the company should have been computerized in a reason of not only it facilitates the implementation of activities in various divisions but also revenue is increased through creative marketing strategies and advanced

Analysis of strengths, weaknesses, opportunities and threats, as well as the formulation of the four factors strategy SWOT analysis should be applied regularly for once a year or when the company feels the need to do so. Through this study, the advantages are maintained and improved, opportunities to conduct investment activities, as well as weaknesses and threats that arise should be addressed and dealt with. Therefore, SWOT analysis needs to be applied properly in a company so that all employees of the company understand what to do, as well as the direction of the vision and mission of the company.

Comparison of the results of studies in similar organizations needs to be done to ensure that the role of information technology positively correlated to customer satisfaction. Analysis of the system in terms of security and technology used will also be necessary. Financial statement analysis and evaluation of the level of consumer confidence and dependency are on product from CMC. Evaluations should be conducted on the performance of the branch office of CMC in 30 other areas and evaluation of the data integration of $\mathrm{CMC}$.

\section{REFERENCES}

[1] K. Kalyanam and S. McIntyre, "The e-marketing mix: a contribution of the e-tailing wars," Journal of the academy of marketing science, vol. 30, no. 4, pp. 487-499, 2002.

[2] S. Baloglu and Y. A. Pekcan, "The website design and internet site marketing practices of upscale and luxury hotels in turkey," Tourism Management, vol. 27, no. 1, pp. 171-176, 2006.

[3] N. Michaelidou, N. T. Siamagka, and G. Christodoulides, "Usage, barriers and measurement of social media marketing: An exploratory investigation of small and medium b2b brands," Industrial Marketing Management, vol. 40, no. 7, pp. 1153-1159, 2011.

[4] D. Anastasi, Mengenal e-business. Yogyakarta, Indonesia: Andi Offset, 2001.

[5] D. G. Taylor and D. Strutton, "Has e-marketing come of age? modeling historical influences on post-adoption era internet consumer behaviors," Journal of business research, vol. 63, no. 9, pp. 950-956, 2010.

[6] R. Varadarajan and M. S. Yadav, "Marketing strategy in an internet-enabled environment: a retrospective on the first ten years of jim and a prospective on the next ten years," Journal of Interactive Marketing, vol. 23, no. 1, pp. 11-22, 2009.

[7] S. Krishnamurthy, "Introducing e-markplan: A practical methodology to plan e-marketing activities," Business Horizons, vol. 49, no. 1, pp. 5160, 2006.

[8] K. J. Trainor, A. Rapp, L. S. Beitelspacher, and N. Schillewaert, "Integrating information technology and marketing: An examination of the drivers and outcomes of e-marketing capability," Industrial Marketing Management, vol. 40, no. 1, pp. 162-174, 2011.

[9] S. Atler, Information System: Foundation of EBusiness. Prentice Hall, 2002.

[10] C. Stoole. (2015) E-business: Just what is it? Downloaded on March 2015. [Online]. Available: http://ebusiness.about.com/industry 
Cite this article as: R. E. Tarigan and K. S. Dewi, "Web-based implementation of e-marketing to support product marketing of chemical manufacturing company," CommIT (Communication \& Information

Technology) Journal 9(2), 73-82, 2015.

[11] P. R. Smith and D. Chaffey, E-Marketing excellence: At the heart of E-Business. Oxford, UK: Butterworth Heinemann, 2005.

[12] I. Clarke and T. B. Flaherty, Advances In Electronic Marketing. Hershey, PA: Idea Group Inc (IGI), 2005

[13] P. Kotler and G. Armstrong, Marketing: An Introduction. London: Prentice Hall, 2004.

[14] J. Burrow and B. Kleindl, E-Commerce Marketing. Ohio, US: Thomson, 2005.

[15] D. Saladin, Manajemen Pemasaran. Bandung, Indonesia: Linda Karya, 2006.

[16] R. Turban, R. K. Rainer, and R. E. Potter, Intro- duction to Information technology. John Wiley \& Sons, 2004.

[17] F. Rangkuti, Analisis SWOT Teknik Membedah Kasus Bisnis. Jakarta, Indonesia: Gramedia, 2006.

[18] A. Hartanto, "Analisis dan perancangan emarketing pada sumber cellular," Bachelor Thesis, School of business and management, Bina Nusantara University, 2012.

[19] E. Ongko, "Penerapan model strategi pemasaran berbasis web pada cellular88," Bachelor Thesis, STMIK IBBI, 2011. 